Journal of Teacher Education for Sustainability, vol. 22, no. 1, pp. 140-164, 2020

\title{
Sustainable Development from the Viewpoint of Iranian English Teachers: Practicing what they do not Preach
}

\author{
Mansoor Ganji \\ Chabahar Maritime University, Chabahar, Iran \\ Elnaz Kargar Arshadi \\ Islamic Azad University, Karaj Branch, Iran \\ Sogand Mahbubzadeh \\ Payame Noor University, Gilan, Iran
}

\begin{abstract}
Considering the importance of sustainable development (SD) in developing countries and lack of research on this topic among Iranian English teachers, this study aims at investigating the Iranian English teachers' awareness and understanding of this concept and the effects of demographic features on their understanding. To this end, a researchermade 48-item validated Questionnaire that consisted of eight scales was administered among 233 English teachers teaching at high schools, private language institutes, and universities. The data were analyzed through content analysis of the open-ended question and quantitative analysis of the Likert-scale items. One-way ANOVA was used to find out about the effects of gender, workplace, teaching experience, and academic degree on teachers' understanding and awareness. The results revealed that although some teachers could not define the term, or provided a general or wrong definition of the term, more than half of the teachers rightly emphasized the economic aspect, protecting natural resources, and caring for present and future lives of people. It was also found that Iranian English teachers highly supported equity, appreciated and protected the nature, enjoyed diversity, asked for education for sustainable development, and led a frugal life. Finally, it was revealed that none of the demographic features influenced teachers' awareness of SD, except for academic degree and workplace factor that affected three out of eight scales measuring SD. The study ends with several implications for materials developers, English teachers, and syllabus designers.
\end{abstract}

Key words: sustainable development, Iranian teachers, awareness, English teachers, gender, workplace, academic degree 


\section{Introduction}

As an important branch of sustainable development (SD), education for sustainable development (ESD) is described as raising public awareness about environmental, social, and economic features of SD (Reid, 2002). A sustainable community demands healthy, knowledgeable, skillful, and active members who are well-informed and highly encouraged to live more sustainably and to assure next generations' quality of life (Biasutti, De Baz, \& Alshawa, 2016; Carban \& Fisher, 2017). The main goals of ESD are to incorporate the principles and practices of SD into all levels of education, to enable individuals to think of their own actions, and to encourage them to consider their present and future social, cultural, economic, and environmental effects (Rieckmann, 2018). To do this efficiently, the knowledge, competences, and dispositions of higher education students must be redirected towards sustainability.

In 2009, a major goal of UNESCO's World Conference on ESD was to emphasize the relation of ESD to all degrees of education and to integrate ESD into teacher education programs to develop, investigate, and share good educational practice (UNESCO, 2009). The university education system can greatly contribute to the sustainable development of a society (Barth \& Rieckmann, 2012; Dickson, Eckman, Loker, \& Jirousek, 2013; James \& Card, 2012). It also plays a significant role in promoting students' knowledge, skills, and attitudes as global change representatives to develop a more sustainable future (Kelley \& Nahser, 2014; Mcmillin \& Dyball, 2009; UNESCO, 2009; Wiek, Bernstein, Foley, Cohen, Forrest, Kuzdas, \& Keeler, 2016; Bernstein, Foley, Cohen, Forrest, Kuzdas, \& Keeler, 2016; Salìte, 2015; Pipere, Veisson, \& Salīte, 2015; Fedosejeva, Boče, Romanova, Ivanova, \& Iliško, 2018).

Regarding the curriculum, education, and instructional methods, a number of studies indicated that ESD was not broadly practiced at universities (Christie, Miller, Cooke, White, 2013), and that there was no link between the teaching practices within ESD literature and instructors' experiences (Cotton, Bailey, Warren, \& Bissell, 2009). As cited by Thomas (2004), there are several reasons, including dearth of institutional support for ESD, instructors' poor perception of ESD, lack of appropriate resources, and pedagogical restrictions made by the traditional instructors and tutorials. Accordingly, the universities are highly recommended to incorporate more studentcentered strategies instead of traditional lectures to integrate sustainability into their practice (Christie et al. 2013; Cotton et al. 2009).

Dealing with sustainability requires knowledge on the part of teachers (Burmeister \& Eilks, 2013); thus, Sinakou, Boeve-de Pauw, Goossens, and Petegem (2018) asserted that a course on ESD had tobe added to teacher education programs to give teachers an opportunity to study the notion of SD systematically so that they could train responsible students (Mogensen \& Schnack, 2010). Teachers should take responsibility to help learners develop the knowledge and skills about SD matters and sustainability challenges (Abdulwali, Alshmrani, \& Almufti, 2017; Hungerford, 2010; Van Gejeka, 2013). However, many teachers are not completely aware of SD themselves and not prepared for ESD (Summers, Childs, \& Corney, 2005; Uitto \& Saloranta, 2017).

Many studies have been undertaken to investigate SD around the world including students' attitudes to SD (Abu-Alruz, Hailat, Al-Jaradat, \& Khasawneh,2018; Onuki \& Mino, 2009; Von Der Heidt \& Lamberton, 2011), students' perceptions of SD (Manni, Ottander, Sporre, \& Parchmann, 2013), evaluation of sustainability (Brito, Rodríguez, \& Aparicio, 2018), teachers' attitudes towards ESD (Effeney \& Davis, 2013; Tomas, 
Girgenti \& Jackson, 2015), teachers' perceptions of ESD (Ambusaidi and Al Washahi, 2016; Anyolo, Kärkkäinen, \& Keinonen, 2018; Tomas \& Mills, 2011; Uitto \& Saloranta, 2017), teacher's views of SD (Selvi, Selvi, Güven-Yıldırım, \& Köklükaya, 2018), and the effect of ESD on students' achievements (Boeve-de Pauw, Gericke, Olsson, \& Berglund, 2015; Tapia-Fonllem, Fraijo-Sing, Corral-Verdugo \& Valdez, 2017). However, there are a few studies conducted in Iran on this issue. Thus, this study aims at filling this gap and investigating the awareness and understandings of Iranian English teachers of sustainable development.

\section{Literature Review}

The significance of education as the central part of SD was highlighted in a summit by UNESCO in 2002 (Amador, Martinho, Bacelar-Nicolau, Caeiro, \& Oliveira, 2015), and it was argued that ESD needs to be integrated into all subjects at all degrees (Åhlberg, Äänismaa, \& Dillon, 2005; Corcoran \& Wals, 2004; Cortese, 2003). However, several scholars claim that this potential is underestimated (Cortese, 2003). Pointing out the challenges of implementing SD in higher education, Bosselmann (2001) declared that traditional approaches of one-sided lecturing limited utility considering the complexity of ESD. As a solution to these problems, most ESD scholars have called for sustainability pedagogies that are based on experience, participation, practice, and inquiry (e.g., Bosselmann, 2001; Christie et al, 2013). These new pedagogies are fundamentally student-centered and include strategies like fieldwork, role plays, discussions, reflective accounts, and critical reading and writing tasks (Christie et al., 2013; Garrard, 2010), representing a significant shift in higher education teaching and learning systems (Sterling, 2012).

According to Kabadayi (2016) and Sterling (2012), the university system is accountable for helping graduates understand the ESD knowledge and skills essential for today and future. As argued by Thomas (2005), the main function of tertiary system is to provide graduates with a great deal of knowledge of SD. Accordingly, ESD courses have been offered by universities to assist students in becoming good citizens locally and globally (Tingey-Holyoak \& Burritt, 2012). Teachers play a vital role in training the children and teenagers to be tomorrow's leaders for protecting the environment (Esa, 2010); thus, we need well-trained teachers to understand the students' problems, to apply technology in teaching, and to use various teaching strategies in this regard (Ambusaidi, 2011). Not lagging behind other countries, the National Committee for Sustainable Development (NCSD) was established in Iran in 1992 to develop plans and strategies corresponding to statements of Rio's Earth Summit Committee (Maknoon, 2006). The directives of the summit which are taken by the Iranian Department of the Environment are inspiring with regard to various challenges in economic, social, and environmental aspects that the government encounters (Bahaee \& Pisani, 2009).

Several studies have been conducted on students' perceptions and attitudes towards ESD. Yuan and Zuo (2013) distributed a questionnaire among 1134 students in China to investigate their perceptions and awareness of SD. The results indicated that students had little awareness of SD, arguing for incorporating more campus operation activities. Pestana and Perreira (2016) investigated Portuguese students' perception of sustainability at a private university studying Human Research Management, as well as the correlation between the management of human resources and SD. Using the questionnaire and 
focus group, the researchers concluded that students were well-informed of SD and they had positive attitude towards it.

On the other hand, other studies have examined teachers' perceptions of and attitudes towards SD. Uitto and Saloranta (2017) investigated sustainability competence of 442 secondary school teachers in Finland. The researchers developed a 53-item questionnaire to collect data from 49 schools and utilized an explorative factor analysis, regression, and ANOVA to analyze data. They found significant differences in teachers' perceptions of their ESD competence. Teachers' age also had a significant effect on teachers' sustainability competence. Selvi, Selvi, Güven-Yıldırım, and Köklükaya (2018) examined 35 teacher candidates' perception of SD studying in various subjects. Using semi-structured interviews, they concluded that teacher candidates did not know the exact definition of sustainable development, but they had only heard of ecological aspect, not knowing anything about its economic, social, or political aspects. Tomas, Girgenti, and Jackson (2015) in a mixed method study investigated pre-service teachers' attitudes towards ESD in Australia. Four-point Likert-scale survey and semi-structured interview were used to gather data. It was found that pre-service teachers' attitudes to ESD improved, their confidence raised, and their ESD-related knowledge developed. However, Brito, Rodríguez, and Aparicio (2018) conducted a study on both instructors and students from four academic departments in secondary schools, undergraduate, and postgraduate programs of Mexico. They recommended that the adequacy of teaching performance in terms of ESD should be evaluated. Having analyzed the above-mentioned literature, one finds that dynamic engagement of teachers and staff in sustainability activities is needed (Sammalisto, Sundström \& Holm, 2015). Lozano et al. (2015) came up with the conclusion that sustainability could not be presented without the cooperation of students, instructors, staff, principals and the society.

To put it in a nutshell, research on ESD has been carried out in various countries, including Australia (Tomas \& Mills, 2011), Finland (Uitto \& Saloranta, 2017), South Africa (Anyolo, Kärkkäinen, \& Keinonen, 2018), Mexico (Brito, Rodriguez, \& Aparicio, 2018; Tapia-Fonllem et al, 2017), the United Arab Emirates (Abu-Alruz, Hailat, AlJaradat, \& Khasawneh, 2018), Sweden (Boeve-de Pauw, Gericke, Olsson, \& Berglund, 2015; Manni, Ottander, Sporre, \& Parchmann, 2013), Turkey (Selvi, Selvi, GüvenYıldırım, \& Köklükaya, 2018), Oman (Ambusaidi \& Al Washahi, 2016), Germany (Burmeister, Schmidt-Jacob \& Eilks, 2013) and Korea (Kang, 2019). Additionally, most studies conducted so far have focused on teachers' perceptions of SD in fields other than English, e.g., chemistry (e.g., Burmeister, Schmidt-Jacob \& Eilks, 2013), and home economics (e.g., Dewhurst \& Pendergast, 2011; Gisslevik, Wernersson, \& Larsson, 2018).

Finally, little research has been conducted on the notion of SD in the Iranian EFL (English as a Foreign Language) context (e.g., Bahaee, Perez-Batres, Pisani, Miller, \& Saremi, 2014; Faham, Rezvanfar, Movahed Mohammadi, \& Rajabi Nohooji, 2017; Mohammadnia \& Deliery Moghdam, 2018; Zare, Zeinalipour, Zaree, \& Mohammadi, 2018). Bahaee, Perez-Batres, Pisani, Miller, \& Saremi (2014) investigated the attitudes and knowledge of university students from various fields about SD at one public university. They concluded that most of the students had positive attitudes towards SD, and the women were found to be more knowledgeable in this regard. However, this study focuses on the knowledge and attitudes of English teachers from various universities and institutes. Furthermore, this study investigates both the attitudes they hold and the 
actions they took to care for SD. Thus, this study could be considered more representative. Faham, Rezvanfar, Movahed Mohammadi, \& Rajabi Nohooji (2017) aimed at finding out the necessary mechanisms for developing ESD in higher education in order to improve the sustainability competences of students. They came up with a new model for education at the university level. Consisting of 18 reinforcing and 6 balancing feedback loops, this model delineated the research problem and prognosticated the model variables for the next 20 years. As can be seen, the research is quite different from the current study in aims, methods, and findings. Zare, Zeinalipour, Zaree, and Mohammadi (2018) focused on textbooks and higher education; they studied the curriculum content design. Using open interviews and qualitative data, the researchers chose 25 faculty members specializing in curriculum, agriculture, civil engineering, and architecture, who all came from Shiraz University. They came up with several organizing themes such as social and cultural, environmental, economic, institutional, each of which consisted of different basic dimensions.

In particular, few, if any, studies have been reported in field of English language teaching and among English-major students and teachers (e.g., Mohammadnia \& Deliery Moghdam, 2018). They analyzed the content of English textbook series authored by the Iranians utilizing UNESCO's Earth Charter and the Roadmap for Implementing the Global Action Program on ESD. The results revealed that the textbooks contained most of the themes and elements of SD, but the distribution of the themes was not equal and balanced across the series and units. It was also suggested that teachers had to play a significant role in the discussion and teaching of these themes. Therefore, this study aims at neglecting the two areas studied so far, the textbooks and university students, and instead focusing on teachers as agents of change, facilitators of knowledge, and role models for students. Considering the importance of English as an international language worldwide and the pivotal role of private language institutes and universities in the education system of English in the Iranian context, the present study serves as the first attempt to investigate the attitudes of Iranian EFL teachers towards the notion of SD. Thus, the following research questions were proposed.

1. What is Iranian English teachers' understanding of sustainable development?

2. To what extent are Iranian English teachers aware of sustainable development?

3. Do gender, teaching experience, workplace, and academic degree influence the Iranian English teachers' awareness of sustainable development significantly?

\section{Methodology}

\section{Design and Participants}

The design of the present study is descriptive and comparative. A total number of 233 teachers, 115 males and 118 females, within the age range of 22 to 60 from different private language institutes (160 teachers), high schools (20 teachers), and universities (53 teachers) across Iran were chosen through convenience and snowball sampling (Dörnyei, 2007). The teaching experience of the teachers ranged from 1 to 40 years; there were low-experienced (158 teachers), mid-experienced (59 teachers), and highlyexperienced (15) teachers. They held BA (63 teachers), MA (133 teachers), and PhD (37 teachers) degrees in teaching English as a Foreign Language, English Literature, Translation Studies, and Linguistics. 


\section{Instruments}

This study used a researcher-made validated 48-item questionnaire to elicit the teachers' perceptions and awareness of SD concept and its related issues. In order to develop this questionnaire, the following steps were taken. First of all, the researchers studied the previous literature in regard to SD and found several questionnaires and interviews developed in the said domain. These questionnaires were mixed, and a 122-item bank was developed. Then, one of the researchers studied these items several times, deleting the repeated and irrelevant items, adding items that were related to the Iranian society and Iran's environmental problems. This led to the reduction of items to 80 , and rephrasing of several items.

The questionnaire was judged by 5 researchers in the field of TEFL, economics, and management to check its content validity. The researchers were asked to evaluate the items in terms of clarity, suitability for the objectives of the study, and the appropriateness of the categorization. To be more exact, they were asked to rate the items on a scale of 1 to 7 , indicating how much each item was relevant to the aims of the research. Those items which were ranked above 5 were chosen as the last items. The researchers' comments and recommendations led to the omission of vague items and the items not related to Iranian culture, the rephrasing of a number of items, and the merging of several items. There were 9 scales in the beginning, but the category of proenvironmental deliberation was added to pro-ecological behavior due to its low reliability, low number of items, and the suggestions of the experts. Thus, 48 items were chosen out of the first 80 items to examine teachers' perception of SD. They were divided into four parts. The number of items in the eight subscales of the questionnaire was as follows: ecological issues (9 items), pro-ecological behavior ( 8 items), frugality (5 items), altruism ( 5 items), equity ( 7 items), appreciation of nature (6 items), education for sustainable development ( 4 items), and affinity towards diversity (4 items). The questionnaire was distributed among 22 participants similar to the target participants. The reliability of the questionnaire was measured using the Cronbach's alpha reliability coefficient. The reliability value of the questionnaire was shown to be 0.815 . This indicated that the present questionnaire enjoyed enough reliability and consistency for collecting the needed data. To be more exact, the eight scales of the questionnaire were tested separately, and the following reliability coefficients were observed: ecological issues (0.91), pro-ecological behavior (0.66), frugality (0.28), altruism (0.63), equity $(0.75)$, appreciation of nature $(0.36)$, education for sustainable development $(0.74)$, and affinity towards diversity (0.54). Since the reliability of frugality and appreciation of nature were low, the items were changed, leading to reliability indices of 0.55 and 0.63 , respectively, in the main study.

The first part of the questionnaire covered demographic information about the participants and their definition of SD. The second part of the questionnaire covered nine environmental problems and issues taken from the Environment and Sustainable Development survey developed by Azapagic, Perdan, and Shallcross (2005), where the respondents had to indicate their knowledge of these issues, using a 5-point Likert scale $(1=$ Not heard of it at all to $5=$ know a lot $)$. In the third part of the questionnaire, the following items were used: eight items of Kaiser's (1998 and Corral-Verdugo (2008)) pro-ecological behavior scale, including actions like recycling, buying seasonal products etc.; five items of frugality scale developed by Corral-Verdugo, Tapia-Fonllem, FraijoSing, Mireles, and Márquez Ulloa (2008), including reusing notebooks, walking instead 
of driving etc.; and five items of altruism scale developed by Corral-Verdugo et al. (2008). All these items were assessed on a 5-point Likert-type options of response, where the participants had to report how often they did the mentioned actions $(1=n o t$ at all to $5=$ very often). In the fourth part of the questionnaire, the respondents had to indicate how much they agreed with the mentioned statements. These items included seven items of equity scale developed by Corral-Verdugo et al. (2008) indicating behaviors like equal educational chance for boys and girls, equal status of different social classes in society etc.; six items of appreciation of nature scale developed by Corral-Verdugo, Bonnes, Tapia, Fraijo, Frías, and Carrus (2009), including positive emotions deriving from contact with nature; four items of affinity towards diversity developed by CorralVerdugo et al. (2009) covering social and human diversity in terms of religion, race etc.; four items of ESD scale developed by Ambusaidi and Al Washahi (2016) evaluating the participants' perception of ESD concept. This group of items was assessed based on a 5 -point Likert-type options of response $(1=$ strongly disagree to $5=$ strongly agree $)$.

\section{Data Collection and Analysis Procedure}

The researchers distributed the questionnaire through google.doc to 233 teachers teaching at different private language institutes, high schools, and universities across Iran to examine how the Iranian English teachers were informed with regard to sustainability issues. The link of the questionnaire (via google.doc) was emailed or sent to the participants through Telegram and WhatsApp. Then they were asked to share the link with their friends and colleagues. Teachers were informed that the data and final results would be kept confidential. The process of data collection lasted from November 2019 to March 2020. Some of the questionnaires which were partially completed were removed, and just those questionnaires with complete responses were employed to answer the research questions.

Data were analyzed using the Statistical Package for Social Sciences (SPSS) version 22. Descriptive statistics such as mean, percentage, and standard deviation were obtained. The data generated by the only open-ended question in the questionnaire was analyzed qualitatively, using content analysis techniques, which provided the answer to the first research question. The second and third research questions were analyzed quantitatively, using descriptive statistics, independent-samples t-test, and one-wayANOVA.

\section{Results and Findings}

\section{Research Question One}

The first question was the only question of the questionnaire for which the teachers had to provide an open-ended answer. They were asked to write their definitions of sustainable development. The answers were typed by the teachers themselves, so it was easy to compile a word file of all the definitions. One of the researchers read the definitions carefully two times to determine the main themes and key words used. The main elements of the definitions were not difficult to find since most of the teachers used a limited number of factors for defining the term. There were eleven categories for the definition. They are presented below in descending order. 


\section{Present and Future}

This was the most frequent definition among the teachers. Forty-eight teachers stated that SD is a kind of development that considers both present and future of human life. There were different wordings for this, but all of them mentioned these two aspects. Two of the definitions are quoted below.

"Development that meets the needs of the present without endangering the ability of future generations to meet their own needs".

"SD means making the world a better place for the present generation without destroying the possibilities for the next ones".

2. Natural Ecosystem and Resources

The second group of teachers focused on the natural ecosystem and resources. They mentioned this idea directly or in rare cases used other terms. Forty-three teachers agreed on this idea that SD means that we should not finish and should take care of natural resources and ecosystem.

"Sustainable development is a way for people to use resources but not running them out."

"It means doing development without damaging or affecting the environment."

\section{Cannot Define}

The third group was exactly the same as the second group in number. There were forty-three teachers who acknowledged that they did not know the definition of the term.

"I have no idea about this."

"I don't know what it means."

4. Continuous Progress

The third group of participants did not offer a better solution than that of the third group. In fact, they defined the term according to their knowledge of English vocabulary and made a wild guess. Knowing that sustainable means lasting for a long time, these thirty-five teachers defined the term as a kind of development that is stable and does not stop.

“An on-going development, I guess. Permanent progress.”

"It means the development that should be continued."

\section{Education and Learning}

The fifth most frequent definition contained some elements of knowledge, education, learning, or teaching. These twenty-two persons believed that SD has to do with the type of learning, and teaching in societies should be presented in a way that it guarantees the development and stable life of future generations.

"To acquire knowledge of teaching general English sustainably, have selfreflection and apply them in your classes to improve them."

"It is what leads to equity, much needed in our Educational System. Sustainable Development is education that encourages changes in knowledge, skills, values and attitudes to enable a more sustainable and just society for all." 


\section{General Definition}

The sixth category included those teachers who did not know the exact definition of the term but made a guess or tried to define it in some general terms. These were brought under the category "general definition", some of which might not be right. There were fourteen teachers in this category.

"SD means development in an inclusive, comprehensive, sustainable and integrated manner."

"It means to take care of all vital aspects of your life and not to ignore or miss your essential needs. It means to have a harmonious development."

7 and 8. Present Needs and Wrong Definition

The next group focused on the present needs while forgetting the future generations. This group included nine persons. Furthermore, seven teachers provided a wrong definition, which did not include any of the aspects of sustainable development.

"Focusing on present needs of human beings for better life."

"...paying attention to the needs of the present moment."

"Sustainable development means abundant."

9, 10, and 11. Complete Definition, Economic Development, and Copied

Six teachers provided a very long definition, containing at least 150 words. They included all the aspects of sustainable development. Four teachers underlined the economic aspect of the concept. Finally, two of the participants copied the definition from the net and surprisingly they acknowledged that they had done so.

"The concept of sustainable development can be interpreted in many different ways, but at its core is an approach to development that looks to balance different, and often competing, needs against an awareness of the environmental, social and economic limitations we face as a society."

"Economic development that is conducted in present."

\section{Research Question Two}

In order to answer the second research question and to identify teachers' awareness of sustainable development and its related issues, descriptive statistics were conducted for each scale and for each item in the scale. Since the questionnaire was divided into 8 subheadings, the results are presented in several tables (Tables 1 to 4 ). Table 1 presents the data regarding ecological issues and altruism scales. 
Table 1

Descriptive Statistics of SD in the Ecological Issues and Altruism Scales

\begin{tabular}{lclr}
\hline \multicolumn{1}{c}{ Items } & Mean & \multicolumn{1}{c}{ Items } & Mean \\
\hline Air pollution & 4.1373 & Contributing financially to the Red Cross & 1.6567 \\
\hline Water pollution & 3.9270 & Giving money to the poor & 3.5064 \\
\hline Climate change & 4.0000 & Giving money to the homeless & 2.9185 \\
\hline Deforestation & 3.7983 & Assisting people who are addict & 1.9614 \\
\hline Global warming & 4.1202 & $\begin{array}{l}\text { Helping elderly or handicapped cross } \\
\text { streets }\end{array}$ & 3.5622 \\
\hline Ozone depletion & 3.5494 & & 2.7212 \\
\hline Overpopulation & 3.9828 & & \\
\hline Greenhouse effects & 3.6652 & & \\
\hline Renewable energy sources & 3.8326 & & \\
\hline Overall mean & 3.8903 & Overall mean & \\
\hline
\end{tabular}

As Table 1 indicates, the items "air pollution" and "global warming" have the highest means $(4.13 ; 4.12)$, which are between the answers "have some knowledge" and "know a lot". This indicates that the Iranian EFL teachers seem to be most awareof these two topics. "Ozone depletion" has the lowest mean (3.54) which is between the answers "heard of but could not explain" and "have some knowledge". The result shows that the teachers are least familiar with this topic. The participants were aware of the rest of the items to some extent. Generally, the total mean of the ecological issues scale is (3.89), which indicates that the teachers have some knowledge about these ecological issues. Most teachers claimed that they 'have some knowledge' or 'know a lot' about all the topics mentioned in this category. However, the results with regard to altruism scale are different. The results indicated that the highest mean belonged to the item "Helping elderly or handicapped" (3.56) followed by the item "Giving money to the poor" (3.50). These two behaviors are rooted in the Iranian culture and religion. The item "Contributing financially to the Red Cross" has the lowest mean (1.65). Helping addicts (1.96) and giving money to the homeless (2.91) were below the average in this category. The reason might lie in the fact that the Iranian people might not trust the governmental organizations and refer to help the poor, addict or homeless people themselves rather than giving their money to organizations. The total mean of the scale is $(2.72)$.

Table 2

Descriptive Statistics of the Pro-ecological Behavior and Frugality Scales

\begin{tabular}{lclc}
\hline \multicolumn{1}{c}{ Items } & Mean & \multicolumn{1}{c}{ Items } & Mean \\
\hline $\begin{array}{l}\text { Bringing empty bottles and } \\
\text { used papers to a recycling bin }\end{array}$ & 3.5966 & Wearing same clothing of last year & 4.2704 \\
\hline $\begin{array}{l}\text { Buying seasonal products such } \\
\text { as cherries in summer and } \\
\text { oranges in winter }\end{array}$ & 4.0601 & $\begin{array}{l}\text { Not buying a new car if old one } \\
\text { functions }\end{array}$ & 3.8627 \\
\hline $\begin{array}{l}\text { Turning down air conditioning } \\
\text { when leaving place }\end{array}$ & 4.5794 & $\begin{array}{l}\text { Reusing notebooks and one-side- } \\
\text { written papers }\end{array}$ & 4.2833 \\
\hline $\begin{array}{l}\text { Encouraging my friends and } \\
\text { family to recycle }\end{array}$ & 3.5236 & $\begin{array}{l}\text { Using most earnings for buying } \\
\text { clothing such as dress, shoes, and shirt }\end{array}$ & 3.8026 \\
\hline
\end{tabular}




\begin{tabular}{|c|c|c|c|}
\hline \multicolumn{4}{|c|}{ Continuation of Table 2} \\
\hline Items & Mean & Items & Mean \\
\hline $\begin{array}{l}\text { Buying products in refillable } \\
\text { packages }\end{array}$ & 3.2232 & Walking instead of driving & 3.4678 \\
\hline $\begin{array}{l}\text { Pointing out unecological } \\
\text { behavior such as breaking a tree }\end{array}$ & 3.5923 & & \\
\hline Planting a tree on the Arbor Day & 2.0901 & & \\
\hline $\begin{array}{l}\text { Buying environmentally-friendly } \\
\text { products }\end{array}$ & 3.1974 & & \\
\hline Overall mean & 3.4827 & Overall mean & 3.9373 \\
\hline
\end{tabular}

It is clear from Table 2 that the participants displayed the pro-ecological behaviors and took actions in this regard to save the nature. The item "Turning down air conditioning when leaving place" has the highest mean (4.57). The item "Buying seasonal products such as cherries in summer and oranges in winter" is the second item with the second highest mean (4.06). The item "Planting a tree on the Arbor Day" has the lowest mean (2.09). The total mean of this scale is (3.48). With regard to frugality scale, the results indicated that two items "Reusing notebooks and one-side-written papers" (4.28) and "Wearing same clothing of last year" (4.27) were the first and second most popular behaviors. It is no surprise since most Iranians are not in a good financial situation these days, and almost more than half of the people have financial problems these days due to the sanctions imposed on the country. However, the lowest mean belonged to "Walking instead of driving", where the mean was 3.46. It seems that the Iranian English teachers are ready to take every other step to protect nature and spend less money, but they are so lazy that they prefer to drive at any price. The overall mean for this scale was 3.93.

Table 3

Descriptive Statistics of SD in Equity and Appreciation of Nature Scales

\begin{tabular}{lclc}
\multicolumn{1}{c}{ Items } & Mean & \multicolumn{1}{c}{ Items } & Mean \\
\hline $\begin{array}{l}\text { Women should have the same } \\
\text { rights as men in society }\end{array}$ & 4.4957 & $\begin{array}{l}\text { I am uncomfortable being in } \\
\text { contact with plants and animals }\end{array}$ & 4.8233 \\
\hline $\begin{array}{l}\text { Both males and females have the } \\
\text { right to education }\end{array}$ & 4.8233 & $\begin{array}{l}\text { Teachers can play an important role } \\
\text { in solving environmental problems }\end{array}$ & 4.1974 \\
\hline $\begin{array}{l}\text { People of different social classes } \\
\text { are equal }\end{array}$ & 4.2318 & It is nice to stay long in natural areas & 4.1545 \\
$\begin{array}{l}\text { There should be no discrimina- } \\
\text { tion between the rich and poor } \\
\text { people }\end{array}$ & 4.4120 & $\begin{array}{l}\text { Being in outdoor locations provides } \\
\text { me well-being }\end{array}$ & 4.1373 \\
$\begin{array}{l}\text { There should be equity between } \\
\text { the two genders in employment }\end{array}$ & 4.3605 & $\begin{array}{l}\text { Places with plants put me in a good } \\
\text { mood }\end{array}$ & 4.6395 \\
\hline $\begin{array}{l}\text { People of different genders are } \\
\text { equal }\end{array}$ & 4.4936 & I feel happy in contact with nature & 4.6552 \\
\hline
\end{tabular}

English teachers must split their time equally between boys and

girls

Overall mean

4.4469 Overall mean

4.4395 
The results from Table 3 revealed that the Iranian EFL teachers advocated equity among the people of different genders and races, which was ranked as the top most scale (4.44). As the results indicated, the item "Both males and females have the right to education" had the highest mean (4.82) and the item "People of different social classes are equal" had the lowest mean in this scale (4.23). The total mean of the scale is 4.44 , which is the highest mean among the eight subscales. It can be concluded that the Iranian EFL teachers believed that there had to be enough equity among different groupsof the society. However, they supported the equal roles of people with different social classes the least. Furthermore, the results indicated that the highest mean value in the appreciation of nature domain belonged to the item "I am uncomfortable being in contact with animals and plants" (4.82), followed by "I feel happy in contact with nature" (4.65). The item with the highest mean is "I am uncomfortable being in contact with plants and animals", which should be reversely scored because of the negative word 'uncomfortable'. The total mean of the scale is (4.43), which is the second highest mean among the eight scales.

Table 4

Descriptive Statistics of Affinity towards Diversity and Education for Sustainable Development Scale

\begin{tabular}{lclc}
\hline \multicolumn{1}{c}{ Items } & Mean & \multicolumn{1}{c}{ Items } & Mean \\
\hline $\begin{array}{l}\text { People of different religions must } \\
\text { be respected equally }\end{array}$ & 4.6824 & $\begin{array}{l}\text { I will include education for sustai- } \\
\text { nability in my future classroom } \\
\text { practice }\end{array}$ & 4.1803 \\
\hline $\begin{array}{l}\text { Different political orientations } \\
\text { should be respected }\end{array}$ & 4.0773 & $\begin{array}{l}\text { I like attending symposiums and } \\
\text { lectures that deal with SD and ESD }\end{array}$ & 3.5708 \\
\hline I can live comfortably anywhere & 3.2017 & $\begin{array}{l}\text { It is important to include education } \\
\text { for sustainability in pre-service } \\
\text { teacher education }\end{array}$ & 4.1202 \\
\hline $\begin{array}{l}\text { People of different races must be } \\
\text { seen equally }\end{array}$ & 4.6695 & $\begin{array}{l}\text { Education for SD should be } \\
\text { included in the school curriculum }\end{array}$ & 4.2618 \\
\hline Overall mean & 4.1577 & Overall mean & 4.0332 \\
\hline
\end{tabular}

The results from Table 4 indicated that the Iranian EFL teachers greatly understood, respected, and enjoyed diversity. Although Islam is the official religion of the country, the participants expressed that "People of different religions must be respected equally" (4.68). This was followed by the item "People of different races must be seen equally" (4.66). On the downside, "I can live comfortably anywhere" had the lowest mean (3.20), and this might be related to the fact that they might not be relaxed living in different environments and climates, and the problem might not be necessarily the people around. The Iranian people mostly like to have a fixed job, house, and position, so they might not be relaxed changing places and living in new places. The total mean of this scale was (4.15). As regards the importance of education for sustainable development, it was found that the Iranian EFL teachers were aware of this concept and highly supported its related policies. The item with the highest mean was "Education for SD should be included in the school curriculum" (4.26) and the item with the lowest mean was "I like attending symposiums and lectures that deal with SD and ESD" (3.57). It seems although 
the Iranian English teachers are supporting the inclusion of this concept in the curriculum and are keen to familiarize the students with this concept, they are not willing to increase their knowledge in this regard themselves. The reason might be that they think they are knowledgeable enough in this regard and need no further instruction. The total mean of the scale was (4.03).

\section{Research Question Three}

In order to answer the third research question and to examine if the teachers' gender, teaching experience, workplace, and academic degree made any significant difference in their awareness of SD and its related issues, an independent-sample t-test was run for comparing gender effects on teachers' awareness, which had two categories. However, a one-way ANOVA was run on the data for comparing other variables with more than two levels. The first part is related to the teachers' gender differences, the results of which are presented below in Table 5 .

Table 5

Independent-Sample t-Test for SD Scales According to Teachers' Gender

\begin{tabular}{|c|c|c|c|c|c|c|c|c|}
\hline & \multicolumn{2}{|c|}{$\begin{array}{l}\text { Levene's Test } \\
\text { for Equality } \\
\text { of Variances }\end{array}$} & \multicolumn{6}{|c|}{ t-test for Equality of Means } \\
\hline & \multirow[t]{2}{*}{ 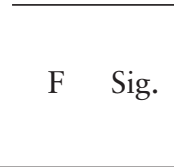 } & \multirow[t]{2}{*}{5} & \multirow[t]{2}{*}{ df } & \multirow[t]{2}{*}{$\begin{array}{c}\text { Sig. } \\
(2 \text {-tailed) }\end{array}$} & \multirow[t]{2}{*}{$\begin{array}{c}\text { Mean } \\
\text { Difference }\end{array}$} & \multirow[t]{2}{*}{$\begin{array}{c}\text { Std. } \\
\text { Error } \\
\text { Difference }\end{array}$} & \multicolumn{2}{|c|}{$\begin{array}{c}95 \% \text { Confidence } \\
\text { Interval of the } \\
\text { Difference }\end{array}$} \\
\hline & & & & & & & Lower & Upper \\
\hline \multirow{2}{*}{$\begin{array}{l}\text { Environmental } \\
\text { issues }\end{array}$} & 1.913 .340 & -1.788 & 231 & .075 & -1.29602 & .72488 & -2.72424 & .13220 \\
\hline & & -1.787 & 229.860 & .075 & -1.29602 & .72530 & -2.72510 & .13306 \\
\hline \multirow[t]{2}{*}{ Altruism } & .001 .977 & .946 & 231 & .345 & .41909 & .44310 & -.45395 & 1.29212 \\
\hline & & .946 & 230.825 & .345 & .41909 & .44280 & -.45335 & 1.29152 \\
\hline \multirow{2}{*}{$\begin{array}{l}\text { Pro-ecological } \\
\text { behavior }\end{array}$} & $.000 \quad .999$ & -2.248 & 231 & .025 & -1.53169 & .68120 & -2.87386 & -.18952 \\
\hline & & -2.247 & 229.042 & .026 & -1.53169 & .68179 & -2.87507 & -.18830 \\
\hline \multirow[t]{2}{*}{ Frugality } & .086 .770 & -3.007 & 231 & .003 & -1.08821 & .36195 & -1.80135 & -.37507 \\
\hline & & -3.009 & 230.823 & .003 & -1.08821 & .36170 & -1.80086 & -.37556 \\
\hline \multirow[t]{2}{*}{ Equity } & 4.019 .046 & -1.917 & 231 & .056 & -1.02690 & .53569 & -2.08237 & .02857 \\
\hline & & -1.913 & 222.007 & .057 & -1.02690 & .53691 & -2.08500 & .03120 \\
\hline \multirow[t]{2}{*}{ Appreciation } & $.263 \quad 609$ & -1.490 & 231 & .138 & -.50081 & .33618 & -1.16318 & .16156 \\
\hline & & -1.489 & 230.485 & .138 & -.50081 & .33627 & -1.16338 & .16175 \\
\hline \multirow[t]{2}{*}{ Affinity } & .998 319 & .303 & 231 & .762 & .09352 & .30818 & -.51369 & .70072 \\
\hline & & .304 & 230.836 & .762 & .09352 & .30797 & -.51328 & .70031 \\
\hline \multirow[t]{2}{*}{ SD } & $.015 \quad 903$ & .142 & 231 & .887 & .04635 & .32611 & -.59618 & .68888 \\
\hline & & .142 & 230.550 & .887 & .04635 & .32619 & -.59634 & .68904 \\
\hline
\end{tabular}

As indicated in Table 5, there is a statistically significant difference between males and females just in two of the scales: pro-ecological behavior $\mathrm{t}(231)=-2.248, \mathrm{p}=0.025$ and frugality $\mathrm{t}(231)=-3.007, \mathrm{p}=0.003$. No significant difference was observed in other six scales, e.g., environment; altruism; equity; appreciation of nature; affinity towards 
diversity and SD concept. The next part of the study was related to the effects of teaching experience on the teachers' awareness and behaviors. The comparison of means of teachers with different levels of teaching experience showed that the three groups were very similar in all scales. However, in order to see if there were any significant differences between these three groups of teachers, one-way ANOVA was conducted. The results are presented in Table 6.

Table 6

One-way ANOVA for SD Scales According to Teachers' Teaching Experience

\begin{tabular}{llccccc}
\hline & & Sum of Squares & $\mathrm{df}$ & Mean Square & $\mathrm{F}$ & Sig. \\
\hline Environment & Between groups & 93.111 & 2 & 46.555 & 1.529 & .219 \\
& Within groups & 6973.678 & 229 & 30.453 & & \\
& Total & 7066.789 & 231 & & & \\
\hline Altruism & Between groups & 77.408 & 2 & 38.704 & 3.486 & .032 \\
& Within groups & 2542.713 & 229 & 11.104 & & \\
& Total & 2620.121 & 231 & & & \\
\hline Pro-ecological & Between groups & 125.306 & 2 & 62.653 & 2.300 & .103 \\
behavior & Within groups & 6239.315 & 229 & 27.246 & & \\
& Total & 6364.621 & 231 & & & \\
\hline Frugality & Between groups & 3.990 & 2 & 1.995 & .250 & .779 \\
& Within groups & 1826.286 & 229 & 7.975 & & \\
& Total & 1830.276 & 231 & & & \\
\hline Equity & Between groups & 4.567 & 2 & 2.283 & .134 & .875 \\
& Within groups & 3914.054 & 229 & 17.092 & & \\
& Total & 3918.621 & 231 & & & \\
\hline Appreciation & Between groups & 1.125 & 2 & .562 & .084 & .920 \\
of nature & Within groups & 1533.962 & 229 & 6.699 & & \\
& Total & 1535.086 & 231 & & & \\
\hline Affinity towards & Between groups & 3.341 & 2 & 1.671 & .301 & .741 \\
diversity & Within groups & 1272.245 & 229 & 5.556 & & \\
& Total & 1275.586 & 231 & & & \\
\hline ESD concept & Between groups & 26.852 & 2 & 13.426 & 2.192 & .114 \\
& Within groups & 1402.734 & 229 & 6.125 & & \\
& Total & 1429.586 & 231 & & & \\
\hline
\end{tabular}

As indicated in Table 6, there was a statistically significant difference between the three groups just in the scale of altruism (F 1,229 $=3.486, P=.032<.05)$. No significant difference was observed in the other seven scales. In order to see where the differences lie among the three groups in altruism scale, a Tukey's post-hoc test was run. The results of the test are displayed in Table 7. 
Table 7

Multiple Comparisons According to Teachers' Teaching Experience

\begin{tabular}{cclcrr}
\hline $\begin{array}{c}\text { Dependent } \\
\text { Variable }\end{array}$ & $(\mathrm{I})$ experience & $(\mathrm{J})$ experience & $\begin{array}{c}\text { Mean } \\
\text { Difference }(\mathrm{I}-\mathrm{J})\end{array}$ & Std. Error & Sig. \\
\hline Altruism & low-experienced & mid-experienced & $-1.2234^{*}$ & .50840 & .044 \\
\cline { 3 - 6 } & & high-experienced & -1.2992 & .90028 & .321 \\
\cline { 2 - 6 } & mid-experienced & low-experienced & $1.2234^{*}$ & .50840 & .044 \\
\cline { 3 - 6 } & & high-experienced & -.0757 & .96355 & .997 \\
\cline { 2 - 6 } & high-experienced & low-experienced & 1.2992 & .90028 & .321 \\
\cline { 3 - 6 } & & mid-experienced & .0757 & .96355 & .997 \\
\hline
\end{tabular}

The table above shows that mean score for altruism was statistically significantly different between low experienced and mid-experienced groups $(p=.044<.05)$. Still another sub-question dealt with the effects of workplace on teachers' awareness of SD. The results with regard to the differences among teachers of different workplaces showed that the mean scores of the three groups were very similar in all scales, and no significant difference could be observed. However, in order to see if there were any significant differences between the groups in each scale, one-way ANOVA was run.

Table 8

One-way ANOVA for SD Scales According to Teachers' Workplace

\begin{tabular}{|c|c|c|c|c|c|c|}
\hline & & Sum of Squares & $\mathrm{df}$ & Mean Square & $\mathrm{F}$ & Sig. \\
\hline \multirow[t]{3}{*}{ Environment } & Between groups & 5.886 & 2 & 2.943 & .095 & .910 \\
\hline & Within groups & 7161.075 & 230 & 31.135 & & \\
\hline & Total & 7166.961 & 232 & & & \\
\hline \multirow[t]{3}{*}{ Altruism } & Between groups & 25.602 & 2 & 12.801 & 1.121 & .328 \\
\hline & Within groups & 2626.072 & 230 & 11.418 & & \\
\hline & Total & 2651.674 & 232 & & & \\
\hline \multirow{3}{*}{$\begin{array}{l}\text { Pro-ecological } \\
\text { behavior }\end{array}$} & Between groups & 15.728 & 2 & 7.864 & .284 & .753 \\
\hline & Within groups & 6363.877 & 230 & 27.669 & & \\
\hline & Total & 6379.605 & 232 & & & \\
\hline \multirow[t]{3}{*}{ Frugality } & Between groups & 26.055 & 2 & 13.028 & 1.660 & .192 \\
\hline & Within groups & 1805.395 & 230 & 7.850 & & \\
\hline & Total & 1831.451 & 232 & & & \\
\hline \multirow[t]{3}{*}{ Equity } & Between groups & 58.132 & 2 & 29.066 & 1.730 & .180 \\
\hline & Within groups & 3864.005 & 230 & 16.800 & & \\
\hline & Total & 3922.137 & 232 & & & \\
\hline \multirow{3}{*}{$\begin{array}{l}\text { Appreciation } \\
\text { of nature }\end{array}$} & Between groups & 7.379 & 2 & 3.690 & .555 & .575 \\
\hline & Within groups & 1527.719 & 230 & 6.642 & & \\
\hline & Total & 1535.099 & 232 & & & \\
\hline \multirow{3}{*}{$\begin{array}{l}\text { Affinity towards } \\
\text { diversity }\end{array}$} & Between groups & 3.401 & 2 & 1.700 & .307 & .736 \\
\hline & Within groups & 1274.857 & 230 & 5.543 & & \\
\hline & Total & 1278.258 & 232 & & & \\
\hline \multirow[t]{3}{*}{ ESD concept } & Between groups & 43.877 & 2 & 21.939 & 3.638 & .028 \\
\hline & Within groups & 1386.998 & 230 & 6.030 & & \\
\hline & Total & 1430.876 & 232 & & & \\
\hline
\end{tabular}


As indicated in Table 8, there was a statistically significant difference between these three groups just in ESD, (F 2,230 = 3.638, $P=.028<.05)$. Thus, there was a difference among teachers based on the place they worked for. In order to see where the differences lie among the three groups in SD concept scale, a Tukey's post-hoc test was run. The results of the tests are displayed in Table 9.

Table 9

Multiple Comparisons According to Teachers' Workplace

\begin{tabular}{lccccc}
\hline $\begin{array}{c}\text { Dependent } \\
\text { Variable }\end{array}$ & $(\mathrm{I})$ workplace & $(\mathrm{J})$ workplace & $\begin{array}{c}\text { Mean } \\
\text { Difference }(\mathrm{I}-\mathrm{J})\end{array}$ & Std. Error & Sig. \\
\hline ESD concept & university & institute & $1.0495^{*}$ & .38919 & .020 \\
& & school & .8245 & .64444 & .408 \\
\cline { 2 - 6 } & institute & university & $-1.0495^{*}$ & .38919 & .020 \\
& & school & -.2250 & .58242 & .921 \\
\cline { 2 - 6 } & school & university & -.8245 & .64444 & .408 \\
& & institute & .2250 & .58242 & .921 \\
\hline
\end{tabular}

The table above shows that the mean score for ESD concept was significantly different between university and institute teachers $(p=.020<.05)$. Finally, the last aim of the research was to find out if the academic degree of the teachers had any influence on their knowledge and behavior with regard to SD. As the results indicated, the mean scores of BA, MA and PhD groups were very similar to each other, and no obvious and great difference could be seen. To see if there were any significant differences between these groups in the said scales, one-way ANOVA was conducted.

Table 10

One-way ANOVA for SD Scales According to Teachers' Degree

\begin{tabular}{llccccc}
\hline & & Sum of Squares & $\mathrm{df}$ & Mean Square & $\mathrm{F}$ & Sig. \\
\hline Environment & Between groups & 8.770 & 2 & 4.385 & .141 & .869 \\
& Within groups & 7158.191 & 230 & 31.123 & & \\
& Total & 7166.961 & 232 & & & \\
\hline Altruism & Between groups & 9.998 & 2 & 4.999 & .435 & .648 \\
& Within groups & 2641.676 & 230 & 11.486 & & \\
& Total & 2651.674 & 232 & & & \\
\hline Pro-ecological & Between groups & 63.782 & 2 & 31.891 & 1.161 & .315 \\
behavior & Within groups & 6315.823 & 230 & 27.460 & & \\
& Total & 6379.605 & 232 & & & \\
\hline Frugality & Between groups & 10.407 & 2 & 5.203 & .657 & .519 \\
& Within groups & 1821.044 & 230 & 7.918 & & \\
& Total & 1831.451 & 232 & & & \\
\hline Equity & Between groups & 10.120 & 2 & 5.060 & .298 & .743 \\
& Within groups & 3912.017 & 230 & 17.009 & & \\
\hline Appreciation & Total & 3922.137 & 232 & & & \\
\hline of nature & Between groups & 40.190 & 2 & 20.095 & 3.092 & .047 \\
& Within groups & 1494.908 & 230 & 6.500 & & \\
\hline & Total & 1535.099 & 232 & & & \\
\hline
\end{tabular}


Continuation of Table 10

\begin{tabular}{llccccc}
\hline & & Sum of Squares & df & Mean Square & F & Sig. \\
\hline Affinity towards & Between groups & 37.165 & 2 & 18.582 & 3.444 & .034 \\
diversity & Within groups & 1241.093 & 230 & 5.396 & & \\
& Total & 1278.258 & 232 & & & \\
\hline ESD concept & Between groups & 67.135 & 2 & 33.568 & 5.661 & .004 \\
& Within groups & 1363.740 & 230 & 5.929 & & \\
& Total & 1430.876 & 232 & & & \\
\hline
\end{tabular}

As indicated in Table 10, there was a statistically significant difference between these groups in three scales of appreciation of nature $(\mathrm{F} 2,230=3.092, P=.047<.05)$; affinity towards diversity $(\mathrm{F} 2,230=3.444, P=.034<.05)$, and ESD $(\mathrm{F} 2,230=5.661$, $P=.004<.05)$. In order to see where the differences lie among the three groups, a Tukey's post-hoc test was run. The results of the test are displayed in Table 11.

Table 11

Multiple Comparisons According to Teachers' Degree

\begin{tabular}{lccccc}
\hline $\begin{array}{c}\text { Dependent } \\
\text { Variable }\end{array}$ & (I) Degree & (J) Degree & $\begin{array}{c}\text { Mean } \\
\text { Difference }(\mathrm{I}-\mathrm{J})\end{array}$ & Std. Error & Sig. \\
\hline Appreciation of nature & $\mathrm{BA}$ & $\mathrm{MA}$ & $-.9290^{*}$ & .38992 & .047 \\
& & $\mathrm{PhD}$ & -.9558 & .52805 & .169 \\
\cline { 2 - 6 } & $\mathrm{MA}$ & $\mathrm{BA}$ & $.9290^{*}$ & .38992 & .047 \\
& & $\mathrm{PhD}$ & -.0268 & .47385 & .998 \\
\cline { 2 - 6 } & $\mathrm{PhD}$ & $\mathrm{BA}$ & .9558 & .52805 & .169 \\
& & $\mathrm{MA}$ & .0268 & .47385 & .998 \\
\hline Affinity towards diversity & $\mathrm{BA}$ & $\mathrm{MA}$ & -.3409 & .35528 & .603 \\
& & $\mathrm{PhD}$ & $-1.2484^{*}$ & .48114 & .027 \\
\cline { 2 - 6 } & $\mathrm{MA}$ & $\mathrm{BA}$ & .3409 & .35528 & .603 \\
& & $\mathrm{PhD}$ & -.9075 & .43175 & .092 \\
\cline { 2 - 6 } & & $\mathrm{PhD}$ & $1.2484^{*}$ & .48114 & .027 \\
& & $\mathrm{BA}$ & .9075 & .43175 & .092 \\
\hline ESD concept & $\mathrm{BA}$ & $\mathrm{MA}$ & $-1.0292^{*}$ & .37242 & .017 \\
& & $\mathrm{PhD}$ & $-1.5363^{*}$ & .50435 & .007 \\
\cline { 2 - 6 } & $\mathrm{MA}$ & $\mathrm{BA}$ & $1.0292^{*}$ & .37242 & .017 \\
& & $\mathrm{PhD}$ & -.5070 & .45258 & .503 \\
\cline { 2 - 6 } & & $\mathrm{BA}$ & $1.5363^{*}$ & .50435 & .007 \\
& $\mathrm{PhD}$ & $\mathrm{MA}$ & .5070 & .45258 & .503 \\
\hline
\end{tabular}

* The mean difference is significant at the .05 level.

The table above shows that mean scores for appreciation of nature were statistically significant between BA and MA groups $(p=.047<.05)$. In affinity towards diversity scale, the mean scores were significant between $\mathrm{BA}$ and $\mathrm{PhD}$ groups $(p=.027<.05)$. Finally, in education for sustainable development scale, the mean score was significant between BA and MA groups $(p=.017<.05)$ as well as BA and PhD groups $(p=.007<.05)$. 


\section{Discussion}

This study, as one of the very few studies on sustainable development among the Iranian English teachers, aimed at finding out about the Iranian English teachers' understanding of sustainable development in order to measure their awareness of this concept and the related issues, and to investigate if their gender, teaching experience, workplace, and academic degree influenced their knowledge and behavior in this regard. To these ends, a questionnaire with one open-ended question and 48 items in Likert scale was distributed among 233 teachers. The results revealed that $18.50 \%$ of the teachers did not understand the term, $3 \%$ provided a wrong answer, $1 \%$ copied the definition from the net, and $6 \%$ defined it in very general terms. This showed that almost a third of the teachers were not able to provide a good definition of the term. These findings are in line with Selvi, Selvi, Güven-Yıldırım, and Köklükaya (2018), who found that the Turkish candidate teachers did not know very much about sustainable development and did not take many actions in this regard. Abu-Alruz, Hailat, Al-Jaradat, \& Khasawneh (2018) also found that Jordanian science education students were not much aware of the environmental pillar of sustainable development. Iran, Jordan, and Turkey are neighbors and all are located in the Middle East, so this is not a big surprise. For one thing, the teaching books used in these countries might not include or emphasize the various aspects of SD. For example, Tuncer, Tekkaya, \& Sungur (2006) reflected that Turkey had not yet integrated the concept of SD in its higher education curriculum. Another reason might be the fact that since environmental aspect of SD is much more familiar and is covered by media and press in different ways, most students might mistakenly believe that this is the only meaning of SD and forget other equally important aspects such as economic, social, political, and educational ones. The last reason is that even if the textbooks contain enough materials regarding SD, teachers might not be well aware of this concept since today's teachers are taught through traditional and old textbooks and methods. Besides, they might have not received enough training and input in this regard in their teacher education programs (Borg, Gericke, Höglund, \& Bergman, 2014). For example, Omani teachers were largely aware of SD concepts, and they reported that they discovered the concept of SD mostly through school textbooks, university courses, the internet, and colleagues. On the contrary, teachers in Turkey did not know much about SD since this concept was not taught in their teacher education programs (Eilks, 2015).

However, around $21 \%$ of the participants rightly emphasized both present and future generations and provided a right definition of the term. Almost $19 \%$ of the teachers stated that sustainable development had to do with nature and natural resources. These findings agree with the results obtained in the study conducted by Ambusaidi and Al Washahi in 2016. They also found that prospective teachers at Soltan Qaboos University had a good and clear idea about the concept of sustainable development. They had almost the same idea about SD. They agreed that SD meant taking care of natural resources for present and future people.

On the downside, some teachers did not have a proper understanding of the term. Those teachers who believed that sustainable development meant making a steady progress in society accounted for $15 \%$. This group also included the teachers who thought that SD meant taking care of present people and needs and neglected the future. This finding finds support from Spiropoulou, Antonakaki, Kontaxaki, and Bouras (2007). They found that the Greek primary school teachers had misconceptions about SD, did 
not do any project in this regard, and confused the related terms. However, these findings are in sharp contrast to the findings revealed by Summers and Childs (2007). In their study, all the 123 student teachers had a clear idea about the term and its related aspects and issues. The student teachers stated that the environmental aspect was the core of $\mathrm{SD}$, followed by economic and social dimensions. The reason may be that these student teachers have studied in such a famous university as Oxford, studied science rather than humanities, and lived in the UK, which is by far more developed than Iran and Oman and cares more about environment and education. Another reason is that the participants in their study mentioned school textbooks as their main source of familiarity with the concept, while the Iranian education system does not contain courses on SD in the English major curriculum.

Comparing the awareness and knowledge of the Iranian English teachers of different aspects of SD, it was revealed that the highest means belonged to equity (4.44), appreciation of nature (4.43), affinity towards diversity (4.15), and education for sustainable development (4.03). These were the categories, where the teachers had to indicate their knowledge, their opinions, or their approval of others' behaviors. These results are in contrast to the conclusions drawn by Abu-Alruz, Hailat, Al-Jaradat, and Khasawneh (2018), who found that the Jordanian students held a negative attitude towards the environmental aspect of SD and did not think that human activities might have catastrophic effects on nature. The reason for this contrast may be the fact that Iran has recently faced several severe natural disasters and environmental problems, and the media have focused on this aspect of SD to a large extent. However, both studies are similar in results regarding the importance of education for sustainable development. This shows that both groups may not be aware of all the aspects of SD, but they feel the need to compensate for these as teachers and material developers. Other researchers have also underlined the importance of nature and natural resources and including ESD in high school books (Anyolo, Kärkkäinen, \& Keinonen 2018; Tomas \& Mills, 2011). Regarding the equity and affinity towards diversity scales, the results are in line with Ambusaidi and Al Washahi (2016). The Omani prospective teachers also felt great affinity towards diversity (3.99) and equity (3.82).

The results regarding the effects of demographic features on teachers' awareness of SD revealed that these features did not influence the teachers' awareness and behavior significantly in most areas. In fact, some features influenced the teachers' awareness in one scale (workplace and teaching experience), or two scales (gender), or three scales (academic degree). Since there were eight scales, and only the academic degree affected three scales, the effects of other variables can be ignored. The results showed that gender of the participants influenced their pro-ecological behaviors and frugality behaviors. These results are in line with the findings of Bahaee, Perez-Batres, Pisani, Miller, and Saremi (2014) who found that Iranian women were more knowledgeable than men with regard to non-technical environmental issues. However, Ambusaidi and Al Washahi (2016) found no difference between men and women regarding their knowledge of different aspects of SD. Teaching experience affected the participants' attitudes towards altruism, workplace affected their opinions about ESD, and the academic degree affected their appreciation of nature, affinity towards diversity, and education for sustainable development. It must be noted that there is little research investigating the effects of these variables on the teachers' awareness of SD scales and aspects, so this study sheds light on these issues and can contribute to our knowledge of these areas. First of all, this is the first study investigating the awareness of the Iranian English teachers regarding 
sustainable development, so it can give us information in this regard and ring the bell in our mind that even teachers are not well aware of the severe problems that human actions might bring about for nature and life. The second way in which this study benefits the English teachers' community is that policy makers and syllabus designers at teacher education universities and teacher training centers have to incorporate this concept in their curriculum and prepare more knowledgeable teachers in this regard.

\section{Conclusion and Implications}

The researchers found that although some Iranian English teachers might not be able to give a complete and correct definition of sustainable development, most of them were to a great extent aware of the issues involved in this area. Furthermore, they did their best, protecting the environment; helping the elderly, handicapped, and poor; taking actions for cleaning the surroundings; and, finally, they enjoyed life with people of different religions and races. It was concluded that teachers with higher degrees did not necessarily know more about most of the scales of SD, nor did they take more actions for sustainable development than lower-degree teachers. Thus, it is apparent that university studies and education do not offer the students very much knowledge and information in this regard. In order to increase the teachers' understanding of sustainable development and educate them as responsible citizens, other aspects of sustainable development must be emphasized in books, magazines, and social media. Since teachers are agents of change and can bring about great changes in the attitudes and knowledge of each society, it is recommended that teachers be trained with regard to sustainable development and its related issues via their teacher education programs. It is also necessary to teach all members of the society while they are still young with regard to sustainable development, its importance, and the ways in which each and every member of the society can take actions to improve the situation. Children can be taught through cartoons, animations, and songs which are broadcast on Iranian national channels and specific programs or movies made for this age group. The findings of this study support well-documented calls for including more lessons and courses at primary schools and high schools and adding at least one course on this issue in the curriculum of all the fields at university. It was also concluded that despite the fact that planting tree was encouraged and pointed out both in the Iranian culture and religion, Iranian teachers were not very keen on planting tree on the Arbor Day. This may be due to the fact that many Iranian families cannot afford to buy plants and trees for planting; thus, the government and the responsible organizations should offer options and sell plants at lower prices to encourage people more in this regard.

This study was one of the few studies, which addressed the awareness and understanding of the Iranian English teachers of SD. Furthermore, it addressed several demographic features and their possible effects on teachers' awareness in this regard, which have been ignored in previous research. Thus, this research has increased our understanding of this issue and provided insights and suggestions for future researchers in this area. Since this study has solely focused on questionnaires for data collection, future researchers can employ interview, content analysis, and document analysis to complement the picture of sustainable development in Iran. They can also compare various fields and majors, but they are suggested to work in humanities and social sciences, where the students are not exposed to such issues in their courses and education. 
Materials developers and syllabus designers are strongly recommended to add some courses at the university level and high schools in order to increase the students' awareness of these issues and help them become more responsible citizens. The least thing to do is to add some chapters, units, lessons, and passages in some of the courses so that the students be exposed to these concepts and obtain information in this regard. Finally, English teachers are suggested to focus on these topics in their discussions and behave as role models for the students.

\section{References}

Abdulwali, H. A., Alshmrani, S. M., \& Almufti, A. N. (2017). Secondary school science teachers' views about their reflective practices. Journal of Teacher Education for Sustainability, 19(1), 45-53.

Abu-Alruz, J., Hailat, S., Al-Jaradat, M., \&Khasawneh, S. (2018). Attitudes toward pillars of sustainable development: The case for university science education in Jordan. Journal of Teacher Education for Sustainability, 20(2), 64-73.

Åhlberg, M., Äänismaa, P., \& Dillon, P. (2005). Education for sustainable living: Integrating theory, practice, design, and development. Scandinavian Journal of Educational Research, 49(2), 167-185.

Amador, F., Martinho, A. P., Bacelar-Nicolau, P., Caeiro, S., \& Oliveira, C. P. (2015). Education for sustainable development in higher education: Evaluating coherence between theory and praxis. Assessment and Evaluation in Higher Education, 40(6), 867-882.

Ambusaidi, A. (2011). Education for sustainable development in Oman. In National journey towards education for sustainable development (pp. 102-116). Paris: UNESCO.

Ambusaidi, A., \& Al Washahi, M. (2016). Prospective teachers' perceptions about the concept of sustainable development and related issues in Oman. Journal of Education for Sustainable Development, 10(1), 3-19.

Anyolo, E., Kärkkäinen, S., \& Keinonen, T. (2018). Implementing education for sustainable development in Namibia: School teachers' perceptions and teaching practices. Journal of Teacher Education for Sustainability, 20(1), 64-81.

Azapagic, A., Perdan, S., \& Shallcross, D. (2005). How much do engineering students know about sustainable development? The findings of an international survey and possible implications for the engineering curriculum. European Journal of Engineering Education, 30(1), 1-19.

Bahaee, M., \& Pisani M. (2009). Are Iranian consumers poised to ‘buy American’ in a hostile bilateral environment? Business Horizons, 52(3), 223-232.

Bahaee, M., Perez-Batres, L. A., Pisani, M. J., Miller, V. V., \& Saremi, M. (2014). Sustainable development in Iran: An exploratory study of university students' attitudes and knowledge about sustainable development. Corporate Social Responsibility and Environmental Management, 21(3), 175-187.

Barth, M., \& Rieckmann, M. (2012). Academic staff development as a catalyst for curriculum change towards education for sustainable development: An output perspective. Journal of Cleaner Production, 26(1), 28-36.

Biasutti, M., De Baz, T., \& Alshawa, H. (2016). Assessing the infusion of sustainable principles into university curriculum. Journal of Teacher Education for Sustainability, 18(2), 21-40. 
Boeve-de Pauw, J., Gericke, N., Olsson, D., \& Berglund, T. (2015). The effectiveness of education for sustainable development. Sustainability, 7(11), 1-25.

Borg, C., Gericke, N., Höglund, H. O., \& Bergman, E. (2014) Subject and experiencebound differences in teachers' conceptual understanding of sustainable development. Environmental Education Research, 20(4), 526-551.

Bosselmann, K. (2001). University and sustainability: Compatible agendas? Educational Philosophy and Theory, 33(2), 167-186.

Brito, R. M., Rodríguez, C., \& Aparicio, J. L. (2018). Sustainability in teaching: An evaluation of university teachers and students. Sustainability, 10(2), 1-16.

Burmeister, M. \& Eilks, I. (2013). An understanding of sustainability and education for sustainable development among German student teachers and trainee teachers of chemistry. Science Education International, 24(2), 167-194.

Burmeister, M., Schmidt-Jacob, S., \& Eilks, I. (2013). German chemistry teachers' understanding of sustainability and education for sustainable development: An interview case study. Chemistry Education Research and Practice, 14(2), 169-176.

Carban, E., \& Fisher, D. (2017). Sustainability reporting at schools: Challenges and benefits. Journal of Teacher Education for Sustainability, 19(1), 69-81.

Christie, B. A., Miller, K. K., Cooke, R., \& White, J. G. (2013). Environmental sustainability in higher education: How do academics teach? Environmental Education Research, 19(3), 385-414.

Corcoran, P. B., \& Wals, A. E. (2004). Higher education and the challenge of sustainability. Dordrecht: Kluwer Academic Publishers.

Corral-Verdugo, V., Bonnes, M., Tapia, C., Fraijo, B., Frías, M., \& Carrus, G. (2009). Correlates of pro-sustainability orientation: The affinity towards diversity. Journal of Environmental Psychology, 29(1), 34-43.

Corral-Verdugo, V., Tapia-Fonllem, C., Fraijo-Sing, B., Mireles, J., \& Márquez Ulloa, P. (2008). Orientation towards sustainability as a determinant of sustainable lifestyles: A study with a Mexican sample. Revista Mexicana de Psicología, 25(2), 313-327.

Cortese, A. D. (2003). The critical role of higher education in creating a sustainable future. Planning for Higher Education, 31(3), 15-22.

Cotton, D., Bailey, I., Warren, M., \& Bissell, S. (2009). Revolutions and second-best solutions: Education for sustainable development in higher education. Studies in Higher Education 34(7), 719-733.

Dewhurst, Y., \& Pendergast, D. (2011). Teacher perceptions of the contribution of home economics to sustainable development education: A cross-cultural view. International Journal of Consumer Studies, 35(5), 569-577.

Dickson, M. A., Eckman, M., Loker, S., \& Jirousek, C. (2013). A model for sustainability education in support of the PRME. Journal of Management Development, 32(3), 309-318.

Dörnyei, Z. (2007). Research methods in applied linguistics: Quantitative, qualitative, and mixed methodologies. London: Oxford University Press.

Effeney, G., \& Davis, J. (2013). Education for sustainability: A case study of pre-service primary teachers' knowledge and efficacy. Australian Journal of Teacher Education, $38(5), 32-46$.

Eilks, I. (2015) Science education and education for sustainable development: Justifications, models, practices, and perspectives. Eurasia Journal of Mathematics, Science \& Technology Education, 11(1), 349-358. 
Esa, N. (2010). Environmental knowledge, attitudes and practices of student teachers. International Research in Geographical and Environmental Education, 19(1), 39-50.

Faham, E., Rezvanfar, A., Movahed Mohammadi, S. H., \& Rajabi Nohooji, M. (2017). Using system dynamics to develop education for sustainable development in higher education with the emphasis on the sustainability competencies of students. Technological Forecasting and Social Change, 123, 307-326.

Fedosejeva, J., Boče, A., Romanova, M., Ivanova, O., \& Iliško, Dz. (2018). Education for sustainable development: The choice of pedagogical approaches and methods for the implementation of pedagogical tasks in the anthropocene age. Journal of Teacher Education for Sustainability, 20(1), 157-179.

Garrard, G. (2010). Problems and prospects in ecocritical pedagogy. Environmental Education Research, 16(2), 233-245.

Gisslevik, E., Wernersson, I., \& Larsson, C. (2018). Home economics teachers' perceptions of facilitating and inhibiting factors when teaching sustainable food consumption. Sustainability, 10(5), 1-16.

Hungerford, H. R. (2010). Environmental Education (EE) for the 21st century: Where have we been? Where are we now? Where are we headed? The Journal of Environmental Education, 41(1), 1-6.

James, M., \& Card, K. (2012). Factors contributing to institutions achieving environmental sustainability. International Journal of Sustainability in Higher Education, 13(2), 166-176.

Kabadayi, A. (2016). A suggested in-service training model based on Turkish preschool teachers' conceptions for sustainable development. Journal of Teacher Education for Sustainability, 18(1), 5-15.

Kaiser, F. (1998). A general measure of ecological behavior. Journal of Applied Social Psychology, 28(5), 395-422.

Kang, W. (2019). Perceived barriers to implementing education for sustainable development among Korean teachers. Sustainability, 11(9), 1-15.

Kelley, S., \& Nahser, R. (2014). Developing sustainable strategies: Foundations, method and pedagogy. Journal of Business Ethics, 123(4), 631-644.

Lozano, R., Ceulemans, K., Alonso-Almeida, M., Huisingh, D., Lozano, F. J., Waas, T., Lambrechts, W., Lukman, R., \& Hugé, J. (2015). A review of commitment and implementation of sustainable development in higher education: Results from a worldwide survey. Journal of Cleaner Production, 108, 1-18.

Maknoon, R. (2006). Cheshm andaze tousea melli va rabbordhaye kalane tousea payedar, [Future national development and strategies for sustainable development]. Tehran: Amir Kabir Engineering University.

Manni, A., Ottander, Ch., Sporre, K., \& Parchmann, I. (2013). Perceived learning experiences regarding Education for sustainable development - within Swedish outdoor education traditions. Nordic Studies in Science Education, 9(2), 187-205.

McMillin, J., \& Dyball, R. (2009). Developing a whole-of-university approach to educating for sustainability: Linking curriculum, research and sustainable campus operations. Journal of Education for Sustainable Development, 3(1), 55-64.

Mogensen, F. \& Schnack, K. (2010). The action competence approach and the 'new' discourse of education for sustainable development, competence and quality criteria. Environmental Education Research, 16(1), 59-76. 
Mohammadnia, Zh., \& Deliery Moghdam, F. (2018). Textbooks as resources for education for sustainable development: A content analysis. Journal of Teacher Education for Sustainability, 21(1), 103-114.

Onuki, M., \& Mino, T. (2009). Sustainability education and a new master's degree, the master of sustainability science: The graduate program in sustainability science (GPSS) at the University of Tokyo. Sustainability Science, 4(1), 55-59.

Pestana, M. H., \& Parreira, A. (2016). Human resources' student's sensitivity to factors of sustainability. Ensaio: Avaliação e Políticas Públicas em Educação, (Essay: Evaluation and Public Policies in Education) 24(91), 337-358.

Pipere, A., Veisson, M., \& Salite, I. (2015). Developing research in teacher education for sustainability: UN DESD via the Journal of Teacher Education for Sustainability. Journal of Teacher Education for Sustainability, 17(2), 5-43.

Reid, A. (2002). Environmental change and sustainable education. In M. Smith (Ed.), Teaching geography in secondary schools (pp. 225-244). London: The Open University.

Rieckmann, M. (2018). Key themes in education for sustainable development. In A. Leicht, J. Heiss, \& W. J. Byun (Eds.), Issues and trends in Education for Sustainable Development (pp. 61-85). Paris: UNESCO.

Salite, I. (2015). Searching for sustainability in teacher education and educational research: experiences from the Baltic and Black Sea Circle Consortium for educational research. Discourse and Communication for Sustainable Education, $6,21-29$.

Sammalisto, K., Sundström, A., \& Holm, T. (2015). Implementation of sustainability in universities as perceived by faculty and staff: A model from a Swedish University. Journal of Cleaner Production, 106, 45-54.

Selvi, M., Selvi, M., Güven-Yıldırım, E., \& Köklükaya, A. N. (2018). Analysis of teacher candidates' views on sustainable development. Journal of Research in Educational Sciences, 5(2), 87-104.

Sinakou, E., Boeve-de Pauw, J., Goossens, M., \& Petegem, V. P. (2018). Academics in the field of education for sustainable development: Their conceptions of sustainable development. Journal of Cleaner Production, 184, 321-332.

Spiropoulou, D., Antonakaki, T., Kontaxaki, S., \& Bouras, S. (2007). Primary teachers, literacy and attitudes on education for sustainable development. Journal of Science Education and Technology, 16(5), 443-450.

Sterling, S. (2012). The Future fit framework: An introductory guide to teaching and learning for sustainability in Higher Education. Journal of Education for Sustainable Development, 7(1), 134-135.

Summers, M., \& Childs, A. (2007). Student science teachers' conceptions of sustainable development: An empirical study of three postgraduate training cohorts. Research in Science and Technological Education, 25(3), 307-327.

Summers, M., Childs, A., \& Corney, G. (2005). Education for sustainable development in initial teacher training: Issues for interdisciplinary collaboration. Environmental Education Research, 11(5), 623-647.

Tapia-Fonllem, C., Fraijo-Sing, B., Corral-Verdugo, V., \& Valdez, A. O. (2017). Education for sustainable development in higher education institutions: Its influence on the pro-sustainability orientation of Mexican students. SAGE Open, 7(1), 1-15.

Thomas, I. E. (2004). Sustainability in tertiary curricula: What is stopping it happening? International Journal of Sustainability in Higher Education, 5(1), 33-47. 
Thomas, T. E. (2005). Are business students buying it? A theoretical framework for measuring attitudes toward the legitimacy of environmental sustainability. Business Strategy and the Environment, 14(3), 186-197.

Tingey-Holyoak, J., \& Burritt, R. L. (2012). The Trans-disciplinary nature of accounting: A pathway towards the sustainable future of the profession. In E. Evans, R. Burritt \& J. Guthrie (Eds.), Emerging Pathways for the Next Generation of Accountants (pp. 93-103). Sydney: The Institute of Chartered Accountants in Australia.

Tomas, L., \& Mills, R. (2011). Preservice teachers' understanding and concern for sustainability issues: Implications for teacher education. Refereed paper presented at 'Valuing teacher education: Policy, perspectives and partnerships', the annual conference of the Australian Teacher Education Association (ATEA), Melbourne, 3-6 July.

Tomas, L., Girgenti, S., \& Jackson, C. (2015). Pre-service teachers' attitudes toward education for sustainability and its relevance to their learning: Implications for pedagogical practice. Environmental Education Research, 23(3), 1-24.

Tuncer, G., Tekkaya, C., \& Sungur, S., (2006). Pre-service teachers' beliefs about sustainable development: Effects of gender and enrollment. Hacettepe University Journal of Education, 31, 179-188.

Uitto, A., \& Saloranta, S. (2017). Subject teachers as educators for sustainability: A survey study. Education Sciences, 7(8), 1-19.

UNESCO. (2009). Bonn declaration. UNESCO world conference on education for sustainable development. Bonn, Germany. Retrieved from: http://www.esd-worldconference 2009.org/fileadmin/download/ESD2009_Bonn Declaration080409.pdf

Van Gejeka, N. (2013). Research into learning process in a vocational secondary school in the context of sustainable development. Journal of Teacher Education for Sustainability, 15(2), 67-77.

Von Der Heidt T., \& Lamberton, G. (2011). Sustainability in the undergraduate and postgraduate business curricula of a regional university: A critical perspective. Journal of Management and Organization, 17(5), 670-690.

Wiek, A., Bernstein, M., Foley, R., Cohen, M., Forrest, N., Kuzdas, C., \& Keeler, L. (2016). Operationalizing competencies in higher education for sustainable development. In M. Barth, G. Michelsen, I. Thomas, \& M. Rieckmann (Eds.), Routledge handbook of higher education for sustainable development (pp. 241-260). London: Routledge.

Yuan, X., \& Zuo, J. (2013). A critical assessment of the higher education for sustainable development from students' perspectives: A Chinese study. Journal of Cleaner Production, 48, 108-115.

Zare, S., Zeinalipour, H., Zaree, E., \& Mohammadi, M. (2018). Sustainable development education curriculum content design in Iran's higher education system: A qualitative study. Quarterly Journal of Environmental Education and Sustainable Development, 6(2), 25-36.

Correspondence concerning this paper should be addressed to Mansoor Ganji, English Department, Faculty of Management and Humanities, Chabahar Maritime University, Chabahar, Sistan and Baluchestan P. Box: 9971756499, Iran. Email: ganjimansoor1980@gmail.com 